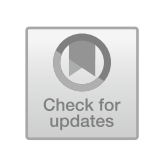

\title{
Modernity, Catastrophe, and Realism in the Postcolonial Indian Novel
}

On 15 August 1947, India gained formal independence from British colonial rule. On the eve of independence, Jawaharlal Nehru, who would soon be India's first Prime Minister, stated in a now famous speech: "Long years ago we made a tryst with destiny, and now the time comes when we shall redeem our pledge, not wholly or in full measure, but very substantially. At the stroke of the midnight hour, when the world sleeps, India will awake to life and freedom." "However, the country's awakening from slumber, from the long histories of colonialism and imperialist subjection to socio-economic and ideological freedom, was not and could not be a smooth one. ${ }^{2}$ The decade of the 1940s saw several enormous moments of national crisis - the Second World War, the 1943-1944 Bengal famine, the communal riots in 1946-1947, and the 1946 naval mutiny in Bombay, just to name a few. The year of independence was bloodied with gruesome violence due to the partition of the colony into two countries, India and Pakistan. In the decades that followed, India would have wars with China and Pakistan, would encounter wide internal discontent surrounding language and caste issues, and agitations from peasants, students and the working classes on issues of food shortage, unemployment, inflation, and poverty. In the 1970s, these crisis conditions would be aggravated by a corrupt Congress Party stewardship led by Indira Gandhi which, in order to save its own image and political priorities, would declare a state of internal emergency in the name of safeguarding democracy from chaos.

S. Bhattacharya, Postcolonial Modernity and the Indian Novel, New Comparisons in World Literature, https://doi.org/10.1007/978-3-030-37397-9_1 
The present book looks at the turbulent period of the first thirty years of Indian history after independence, between 1947 and 1977. It does not read these years as isolated from what came before because of the historical rupture of independence. To the contrary, it seeks to understand how the economic and political crisis in the late-colonial period shaped the social conditions and cultural values in the postcolonial aftermath. It reads late-colonial as a temporal marker denoting roughly the second quarter of the twentieth century, shortly before the formal ending of colonialism. Although independence is the nominal break between the late-colonial and the postcolonial, the book argues through a reading of a longer framework of historical crisis and catastrophe, of structures of domination and acts of resistance that there is hardly a notable conceptual or categorical break there. Rather, this whole period appears as a time of crisis-in-continuity. ${ }^{3}$

The main framework of this book is built around literary works of the three catastrophic events-the 1943-1944 Bengal famine, the 19671972 Naxalbari movement, and the 1975-1977 Indian emergency. Catastrophe is understood to be "an event causing great and usually sudden damage or suffering." 4 While the term has been recurrently used for environmental issues, I use catastrophe here to mean a historical event resulting in tremendous violence and damage of human and nonhuman lives. I argue that the above-mentioned events are "historical catastrophes" as they are linked with the long-term agrarian and food crisis in India which began from mid-nineteenth century onward with the British colonial changes in agriculture, irrigation, and revenue laws. They have made tremendous impact on life and living in postcolonial India. My understanding of modernity in this book arises from its relation with the colonial-capitalist modernisation programme and its (historical) catastrophic repercussions in the postcolonial period. I employ an original method of reading long-term crisis and its link with catastrophic events here. Drawing variously from Louis Althusser, Fredric Jameson, Shahid Amin, and Veena Das, the book argues that a historical event is as much a crystallisation of a long-term socio-historical crisis as it is an interactive amalgamation of different contemporary spatio-temporal events. Although these events have emerged from a particular crisis and led to related events, they are specific in their nature, character, and orientation. The book further contends that their specificity and relatability can be best understood by the aesthetic and fictional techniques of memorialisation and representation that they have given birth to. A close reading of 
these fictional techniques, the book posits, can offer us enabling insights into the deeply connected yet highly heterogeneous histories of Indian postcolonial modernity.

The main contention in the book is that novels have represented the relationship between crisis and events through an innovative use of realism. While realist form has been used to address the immediate socioeconomic crisis and the dynamics of postcolonial optimism and disillusion, a number of highly experimental and diverse modes have been employed to reproduce the deep impact and the specific nature and orientation of the events. I show here that the choice of these modes which range from melodramatic, metafictional, quest, to urban fantastic, magical realist, critical realist, and others (many of which are conventionally understood as anti-realist or non-realist) is deeply historically shaped. Their experimental condition is marked as much by the form and nature of the events as by the proximity of the novels to them. Because my focus in this book is to study through the diversity of realist modes the orientation and function of catastrophic events and related socio-economic crisis, I group these modes around the events themselves and argue for different sets of realisms coming out of them, such as "disaster realism," "critical irrealism," and "emergency realism" in the postcolonial context. Together, I read these realisms as catastrophic realism, which I argue is the aesthetic fabric of catastrophe-prone, crisis-ridden vulnerable condition of life and living in postcolonial India.

\section{The Historical Context: The Theory of Modernisation AND Modernity}

In Modern India (1983), Sumit Sarkar tells us that the process of modernisation in India began in the nineteenth century, as the British started to systematically "underdevelop" India through deindustrialisation and the commercialisation of agriculture in order to turn the flourishing world market of cotton into a raw material for export to Britain. ${ }^{5}$ After Britain's restriction on export to India in 1843, factory-machines for cotton production were imported, and agriculture was further commercialised with irrigation, railways, and the telegraph. Bishnupriya Gupta adds that although there was commercialisation of agriculture, irrigation was limited to particular sectors. It did not help the development of the agricultural sector as a whole. The turn to cash-crop production included priorities given to tea, jute, coal, and other profitable resources over those 
of the foodgrains. ${ }^{6}$ And, as economic historians such as Amiya Bagchi have argued, there was a strong case of racial discrimination in colonial policy, where the native industrial class's entry into the production market was limited. Bagchi also reasons that the shift away from manufacturing (handicrafts and small-scale industries) to agriculture and cash crops brought down India's GDP and curbed its growth. ${ }^{7}$ The modernisation of industries and agriculture contributed significantly to an unequal and uneven system of growth that made India, though a stable economy even during the mid-twentieth century, into an irredeemably poor one. The consequences were seen in a number of disasters in the late nineteenth century. As Sarkar writes, "The colonial structure, as a whole [...] constituted a 'built-in-depressor' for India's agrarian economy. The most obvious indication of this lay in the series of disastrous famines, in the $1870 \mathrm{~s}$ and again in the late 1890s, the latter wave coinciding with the ravages of plague - while twenty years later even influenza managed to kill off millions." 8

What these studies indicate is that colonial modernisation always and by definition occurs in the "catastrophic" mode. The Bengal famine, with which my chapter readings begin in this book, has direct links with the changes in agricultural production, modernisation, and industrialisation in the colony. The Second World War, accompanied by climactic conditions, corruption among traders, and the operation of speculative capital, aggravated the situation. The post-famine society saw increasing deprivation, oppression, and eviction of the peasants by the landed elite. This resulted in the Tebhaga Movement (1946) in Bengal, which was part of a series of social movements in late-colonial India. ${ }^{9}$ Tebhaga was followed by a longer armed struggle by the peasants of Andhra Pradesh against the Nizam and the Indian armed forces, known as the Telangana Uprising (1947-1952). ${ }^{10}$ These insurgencies were organised by the peasants' and workers' fronts of the Communist Party, which was also instrumental in organising food movements in the cities in late 1950s and early 1960s. The crises in food and agriculture were escalated by inflation. Jawaharlal Nehru's death and Indira Gandhi's rise to power in the mid-1960s marked a shift in politics, especially in her heavy commercialisation of agriculture through the Green Revolution project which had the effect of making already rich farmers even richer. Gandhi's economic reforms failed to address the wide uneven development in rural India, the unending peasant oppression, the new nexus between the landed elite, 
political heads, and the police, etc. As the old problems of deprivation and oppression continued, peasants in Naxalbari rose in arms in 1967. The uprising continued for five years until brutally crushed by the state. Soon, Gandhi, unable to tackle the crisis in agriculture, employment, inflation, and economy, and fearful of the rising dissatisfaction with her government, declared a state of emergency to coercively "discipline" the postcolonial public and to pave the way for "neocolonialism" in the name of development. Indian postcolonial democracy now entered a new phase of state authoritarianism and regimentation. Ranajit Guha wrote a fiercely critical essay on the emergency measures. In an argument similar to what Frantz Fanon wrote in "The Pitfalls of National Consciousness" in the late 1950s, Guha contended that true democracy never actually existed in India because decolonisation did not destroy the old colonial state, but only transferred interest and power from the British ruling bodies to the Indian ruling classes. The artificial and state-imposed version of democracy lost credibility when, five years after the liberation of India from colonial rule, the Nehruvian government brutally crushed a peasant movement which demanded landholding and better crop share rights in Telangana. The dead body of democracy was clearly buried in the state's autocratic-repressive acts in the Naxalbari tribal-peasant uprising. The emergency, thus, was not a radical break from a culture of democracy, as the passive opposition would say: "It [wa]s [rather] the realization by the ruling classes, acting through the government of the day, of the full potential of the violence of a state which they had themselves conceived of and set up as hostile to democracy."1l

These aspects of catastrophe, violence, and resistance, produced by capitalist modernisation and bourgeois political dominance in the postcolony, are read here as the social condition of modernity in post/colonial India. ${ }^{12}$ Here my use of the term "modernity" draws critically on Fredric Jameson's use of it. In A Singular Modernity (2005), Jameson writes that modernity is "the new historical situation, modernization [i]s the process whereby we get there, and modernism [i]s a reaction to that situation and that process alike, a reaction that can be aesthetic and philosophicalideological." 13 Modernity as a historical situation is "new" because older feudal and tribal economic modes have been dismantled, because methods of capitalist accumulation never seen before have arisen, and because innovations in technology and machinery have emerged (like the observations in Indian colonial context above). Here, Jameson is careful enough 
to use the word "situation" in a Sartrean sense to suggest the contingency and limits of a particular situation and the desire to break free from the dominant frameworks and to achieve social freedom. ${ }^{14}$ Modernity as a historical situation retains within its framework this dialectic of dominance and resistance, and is not to be understood in liberal terms, as "progress." However, Jameson's framework of break and continuity does not allow this dialectic to be understood through a periodisation of shorter periods, which is key for my theoretical framework.

At an early point in his book, Jameson defines break and continuity as twofold movements sharing a dialectical relation. Historical continuity is the "insistent and unwavering focus on the seamless passage from past to present [which] slowly turns into a consciousness of a radical break; while at the same time the enforced attention to a break gradually turns the latter into a period in its own right." 15 The consciousness of continuity gives birth to the radical consciousness of breaks and consequently of periodisation. Jameson here has a longer history in mind, in which he finds two radical breaks, namely the ancients with their pre-modernity and the European Renaissance with its pre-modernity. What marks this second break and the consequent periodisation is the capitalist mode of production, which proceeds to subsume historical differences under a unilateral logic of global accumulation. For Jameson, these two breaks are not gaps or discontinuities in the Foucauldian epistemic sense. These are new paradigms that have dissevered most of their connections from previous ones. He writes:

$[\mathrm{F}]$ or if the break is initially characterized as a perturbation of causality as such, as the severance of the threads, as the moment in which the continuities of an older social and cultural logic come to an incomprehensible end and find themselves displaced by a logic and form of causality not active in the older system, then the renewed and mesmerized contemplation of the moment of such a break, as it begins to detect causalities and conferences not previously visible to the naked eye is bound to expand that break into a period in its own right. ${ }^{16}$

In this longue durée framework, Jameson finds aesthetic modes to be "transitional" in character. Speaking mainly of the capitalist mode of production, he writes that a new economic mode results in a new historical consciousness and a new temporality. But very much like the paradigmatic nature of economic modes, where the existence of other modes either lies 
hidden or is at their nascent stage, aesthetic modes also contain many temporalities. Taking after Étienne Balibar, Jameson posits that in periods of great economic and social transition, these different temporalities reveal their coexistence in the form of differential aesthetic techniques, which constitute the axis of modernism. ${ }^{17}$

While I agree with these formulations, my point is that, moments or events of extreme historical crisis that shape the experience of modernity - such as famines, social movements, brief dictatorial regimes, or coups-do not necessarily suggest a constitutive break or result in a historical consciousness formative of a new period. However, these events do give birth to new aesthetic modes in order to adequately represent the specificities of the historical catastrophes, crises, conjunctures, and contexts. Indeed, as I will show, sometimes multiple modes-even ones that seem contradictory on the surface, such as the gothic and the social realist-are juxtaposed in a literary work which is based on a catastrophic crisis and is predominantly realist in form. I will argue that the general modern condition of catastrophe and crisis, produced by historical/global factors or by neocolonialism in India, calls for a broad realist framework, while the specific/local conjuncture of a crisis like famine or political uprising inspires the use of specific modes.

This reading of post/colonial modernity, shaped by historical crisis and catastrophic events, is important for the context of my book for two main reasons. First, unlike Jameson's longue durée framework, I am focusing on a shorter time frame, namely the late-colonial and postcolonial period. While the crisis in Indian agriculture, as I have argued above, had a long history of British commercialisation, events like the famine or the political uprising were conditioned and shaped significantly by the immediate and escalating crises in politics and history, such as the Second World War (for the Bengal famine), militant Leftism (for the Naxalbari movement), and the rise of an opposition coalition party (for the emergency). Even if we view this period of forty-odd years of post/colonial modernity (1930s1970s) in terms of the long twentieth century, the historical conditions of imperialism, capitalism, and colonialism, and the practices of political resistance to both the British and the bourgeois native, are so overpowering that the entire post/colonial time frame can together be called a break and one long period in Jamesonian terms. ${ }^{18}$ On the other hand, we will need an elaborate theorisation to understand the historical specificities and crisis conjunctures of the post/colonial period. Second, although all these catastrophic events share a common link with food and agricultural 
crises, they are also different from each other in type, nature, and character. A famine or starvation may have led to a peasant uprising, which may then have been followed by repressive state action, but these are all constitutively different kinds of events. A famine and an agrarian-based political uprising may include wide scenes of violence, but the immediacy and immensity of a famine are not comparable to the long deprivation, dispossession, and violence against peasants by the landed elite, or to the violence produced by guerrilla warfare waged by tribal-peasants. These different catastrophic events constituting Indian postcolonial modernity ask for different modes of expression, which in turn shape the form of realist representations. I will argue in this book that these historically and culturally specific modes, in their late-colonial South Asian/Indian context at least, are able to capture the tensions between the global and the local, between the European-colonialist shaping of uneven modernity and the national/specific responses to it, and between domination and resistance. In order to understand this aesthetic-historical matrix of modernity, we will need a theorisation of crisis and event in the Indian post/colonial conjuncture.

\section{The Dialectic of Crisis and Event}

In her book Critical Events (1995), Veena Das defines events as those that share relations with several institutions "moving across family, community, bureaucracy, courts of law, the medical profession, the state and multinational corporations," and bring about new modes of action redefining traditional categories of knowledge production. ${ }^{19}$ She takes from François Furet's notion that the French Revolution was the event par excellence as it "instituted a new modality of historical action which was not inscribed into the inventory of that situation," 20 and proceeds to critically read the events of the Partition, the Sikh militancy, the Bhopal gas disaster and others focusing on the violence perpetrated on socioeconomically, sexually, and religiously marginal bodies and communities. She finds that over time, victim communities have emerged as powerful political actors, both in terms of declaring their representative authority over their voices and bodies through an antagonistic politics against the state, and consolidating the communities' power through the memorialisation of the pains and sufferings of the members. ${ }^{21}$ Das' main interest here lies in recovering the individual voices, which have been either 
maligned by the state or glorified by the communities in the acts of declaring legitimacy over the pain shared by the subjects of those communities. In both cases, she says, there is a misreading of pain and suffering and an eliding of individual, dissenting, contingent voices by viewing them as irresponsible, accidental, or immoral. An anthropologist herself, Das attempts to read the nature of irresponsibility with responsibility and to give voice to the unheard and the subaltern: "The anthropologist must appear not in the role of an observer but that of a hearer, and the subject must correspondingly appear in the role of a speaker" and recover the disembodied voice. ${ }^{22}$ These ideas prompt me to understand the events and their aesthetic reception from the grounded perspective of victim communities and motivate me to identify and complicate literature's task of giving voice to the unheard and the routinely silenced.

But a problem arises with Das' conception of totalities and resistant practices. She writes,

To recover such embodied narrations [voice] seems to me the only way in which one can resist the totalizing discourses that become evident not only in narratives of the state and narratives embedded in the professional organization, but also in the discourses of resistance that use the vey logic of the state which they seek to resist. ${ }^{23}$

By totalising discourses, as her chapters show, she means the way the state often tries to abstract or reify the contingent and individual cases of pain and suffering through legal and judicial practices and through a recourse to universal humanism. "Discourses of resistance" stand for the practices, strategies, and rhetoric used by the victim communities to appropriate the contingent cases and challenge the state. "A critique of the state," as she writes, "which reproduces the very logic it seeks to contest and which exists in the same arena of historicity can do little more than mirror the state's structures." 24 These observations are problematic on two grounds. There is an a priori understanding that all resistant practices and elements in a given community will support the community's statist counter-practices, and resistance structures are considered a monolithic ideal type. To take one example from our readings, the emergency produced two distinct narratives: one official, one-sided, statist propaganda, and the other oppositional (political and legal narratives and social commentaries published just after the lifting of the emergency). The latter was also using statist discourses of meaning appropriation by declaring 
legitimacy on the sufferers' bodies (reifying their individual experiences), asking for punishment of the culprits, and asserting justice. But in the latter group, there were also competing narratives such as the underground newsletters, pamphlets, or journalistic criticisms. They were opposed to the emergency since the beginning in languages that were either extremist or moderate, but in both cases highly self-reflexive. There were literary and artistic cases of resistance that challenged the authoritarian regime and questioned the validity of statist and counter-statist discourses in rendering the constructed nature of truth. Das' theorisation is unable to address this layered and complex case of (literary) resistance-which points at literature's complex task of and differential logic from the sociological in giving voice to victim communities. Secondly, totalities, as Hegel, Marx, or Lukács understood it, do not mean an appropriation of competing voices for a statist discourse (which sounds closer to the term totalitarian), but rather are ensembles where competing, disruptive, dominant, and residual elements constitute history and society. As we will shortly see through Georg Lukács, a practice of totality, for a writer, is an understanding of the paradoxical fusion of social dissonances through a dialectic of the everyday and the historical. ${ }^{25}$ Interestingly, Das seems to do a similar thing as she theorises pain and suffering from the Wittgensteinian concept of communicability (that pain is social) and inalienability (that pain is physical-conceptual), and adds that "there is no individual ownership of pain." 26 It is through retaining the specificity of the individual and trying to establish a community of suffering via the historicisation or collectivisation of pain, that an anthropologist, and for that matter a writer or literary critic, it seems to me, can break open the totalities of social relationships.

Historian Shahid Amin's understanding of "event" in his book, Event, Metaphor, and Memory (1994) enriches Das' use for my context. Amin reads the history of a peasant riot in the Chauri Chaura village of the northern state of Uttar Pradesh in 1922, which caused Mahatma Gandhi to suspend the Civil Disobedience movement. The event was born both of the long history of fear and hatred for the colonial masters and their symbolic-repressive machineries (the police, the guns, and uniform, etc.) and of the immediate violent skirmishes between the armed police and an unarmed demonstrating satyagrahi-volunteers (Gandhi's political followers who sought truth through nonviolence). Considered a serious flaw in the nationalist/Gandhian anti-colonial campaign, the event was initially obliterated from the official nationalist narratives and the public processes 
of memorialisation, and repurposed later as an instance of "politics by other means." Amin seeks to reconstruct this erased and maligned event through memories and cultural acts of remembrance by the current relatives of the "rioters." He traces through oral narratives, as well as through various bureaucratic and newspaper documents and political pamphlets, how this event was related to both local peasant practices and the imaginings of Gandhi as a messiah, and how through such acts official nationalist narratives appropriated, displaced, and co-opted local resistant practices. An event achieves a double meaning here, as one "fixed in time and also as a metaphor gathering significances outside this time-frame." 27 This is a powerful reading, as it tries to balance the actual (official) course of the event with the way the event was received and used in official as well as unofficial speech and writing. It makes the event into both a singular historical marker and a symbolic construct. At the same time, in order to emphasise the element of public memory and the localisation of the discourse, Amin's work, which follows a method of microhistory, is not able to tell us how this event was connected to the current political crisis in nationalism, especially with the wide rise of native armed struggles and "terroristic" activities, and the contemporary nationwide instances of peasant resistance (the wider historical-metaphorical dimension of the event, so to say).

Althusser's reading of the historical event appears useful in addressing this gap in Das' and Amin's theorisation. Althusser writes in the appendix of the essay, "Contradiction and Overdetermination" (1969):

What makes such and such event historical is not the fact that it is an event, but precisely its insertion into forms which are themselves historical, into forms which have nothing to do with the bad infinity which Engels retains even when he has left the vicinity of the original model, forms which, on the contrary, are perfectly definable and knowable (knowable, Marx insisted, and Lenin after him, through empirical that is non-philosophical scientific disciplines). An event falling within one of these forms, which has the wherewithal to fall within one of these forms, which is a possible content for one of these forms, which affects them, concerns them, reinforces or disturbs them, which provokes them or which they provoke, or even choose or select, that is a historical event. ${ }^{28}$

The context of this formulation arises from Althusser's understanding of overdetermination, which he says is present in Marx's and Engels' works, but which the dogmatic "disciples" have ruled out in their economism, 
empiricism, and determinism. Althusser here explains the content of a letter Engels wrote to J. Bloch in 1890, where Engels clarified that the mode of production was determinant only "in the last instance"; "the various elements of the superstructure"-political, religious, juridical, legal, and literary- "also exercise their influence upon the course of the historical struggle, and in many cases preponderate in determining their form." ${ }^{29}$ In the Russian Revolution, which is his object of study, Althusser finds a principal contradiction between forces and relations of production (a socially backward country and the presence of an advanced imperialist/capitalist condition); but there are also different conditions of existence, different circumstances, national and international in context, "with their own consistency and effectivity" which "merge into a real unity" in a time of crisis and give birth to this revolutionary rupture. These "radically heterogeneous" elements range from political and ideological structures to specific regional customs, habits, national traditions, international political contexts, etc. ${ }^{30}$ They accumulate over time and exacerbate the principal contradiction. Althusser does not see a particular historical-catastrophic event, such as the French Revolution, as a radical break in the way Furet or Das does, as an exception giving birth to new modes of relations and actions. For him, an event is rather the consolidation of a crisis in various forms, their "overdetermined contradiction." Unlike in Hegel-at least as Althusser reads him ${ }^{31}$ — where the organic totality of structures is shaped by "an internal principle" or "abstract ideology," 32 in Marx totality becomes a dialectic between the economic and the associated set of structures which accumulate over time, crystallise and transform into an overdetermined, historical event. Overdetermination becomes the "accumulation of effective determinations (deriving from the superstructures and from special national and international circumstances) on the determination in the last instance by the economic." 33 So, the historical (catastrophic) event that he refers to in the quote is an event because all forms of its condition of being (base and superstructure, so to say) are overdetermined as historical and knowable. In this, Althusser offers us a more historically grounded definition where the catastrophic event is a culmination of a series of events (crisis-forms) that are heterogeneous and possibly antagonistic between themselves, but which also fuse together to produce the revolutionary rupture. These various forms of effects concern, reinforce, and provoke one another to shape the meta-narrative of the historical event and struggle. Althusser uses the Gramscian word 
"conjuncture" to remind us that these events are specific in their context, and global in their world-historical relations and meanings.

To come back to our context of late-colonial India, the disaster condition of the famine was affected by other events such as the War, climactic conditions, hoarding of grain by corrupt traders, etc. An analysis of the event must be conducted through an investigation into how the various dimensions of the crisis of a historical conjuncture produced mini-events, in which the possibility of the rise of a greater historical-catastrophic event of rupture lay hidden. The crystallisation of a period's historical crisis into a catastrophic event has to be understood through the event's accumulated, layered nature. At the same time, the form, orientation, and character of the event also need to be considered. The Bengal famine is an example of an environmental catastrophic event. But famine as an environmental catastrophe is different from other kinds of catastrophes such as cholera, earthquake, and landslide. In fact, no two famines have the same historical orientation and form. If we compare the 1943 famine with another famine, such as the Bombay famine of 1875-1876, we can find many similarities in the causes-and-effects due to similar historical forces responsible for them, but there are also important differences because of the different forces and relations of production and the different evolution and adaption of historical-cultural factors. This is why this historical investigation into the event will also need a critical reading such as Das' or Amin's, where an event's particular nature and the formation of victim communities through resistant acts and discursive strategies as well as through recovery of erased and marginalised documents are given seminal attention, where the writer's, or potentially a literary critic's, role is understood as revisiting the catastrophic events, listening to the complex nature of pain and suffering, to the silences and gaps in the speech practices of the victimised and underprivileged, and transforming these beings into active speakers, giving voice to their suffering.

This discursive, historical materialist method is further useful for my context, as I will be reading literary form of novels registering catastrophic events. My argument here is that novels, for their specific generic conventions and historical-cultural link with capitalist modernity, are able to address the subtle relation between historical crisis and catastrophic event through an ingenious use of form and mode. While form represents the long-term social crisis, it is through mode that authors portray the specificity of an event and allow the possibility (or sometimes the failure) of giving voice to a community. I will further argue that socially committed 
writers have used the realist form to represent the crisis moments. But because of the interactive and experimental use of form and mode, this realism has appeared to be deeply layered and diverse. In the following sections, thus, I will engage with the dynamics of realism through a close study of form and mode to understand how literary-aesthetic elements can offer us crucial insights into the relation between crisis, catastrophe, and representation.

\section{The Dynamics of Realism: Understanding Form AND Mode}

A long-debated issue in academic circles, realism is understood as the manner through which a work of art imitates and registers the workings of the world. It is both a philosophical/epistemological category and an aesthetic form. Epistemologically, it means there is a world "out there" and that it is in principle possible to register the world through the medium of language, paint, camera, or others. The method or the set of formal techniques through which the world is represented is what composes the aesthetic part. Novelistic realism, as Ian Watt tells us, arose with the rise of industrial capitalism and Enlightenment values in the seventeenth- and eighteenth-century European world. Watt considers realism as a set of techniques that were meant to represent an older society's transition to capitalist modernity in seventeenth- and eighteenth-century Europe. ${ }^{34}$ Raymond Williams notes that because of the term's historical link with philosophical schools such as nominalism, conceptualism, and others, there was a long debate within novelists as to what constituted real in realism. ${ }^{35}$ A representation was considered "realistic" which could reproduce objects, characters, actions, and situations in a lifelike manner. But such a representation, writers were acutely aware, focused on the superficial appearance of reality. There is first the barrier of language through which the realist is mediated, and then the elements of individual emotions, feelings, social and historical forces operating behind the appearance of reality in a particular way. ${ }^{36}$ For Williams, realism was not a static form but "a conscious commitment to understanding and describing these forces." 37 Georg Lukács, who is often credited with the critical popularity of the term, states that realism is achieved when an author situates a social "type" in a protagonist, in whom all the socially and historically determining elements are active. Realism captures a "problematic" individual's negotiations with the pressures of capitalist society and 
reveals in the act the totality of structures unavailable to the fragmenting perspective of the individual. ${ }^{38}$ For Lukács, unlike Watt, realism is not a set of formal techniques or a method of producing verisimilitude, but rather a historical process which is forged through a writer's deep historical consciousness and his/her commitment to uncovering the economic, political, and social forces influencing an individual's feelings, decisions, and actions. ${ }^{39}$

In their understanding, realism is thus mainly a formal element. Literary form, as Raymond Williams notes, is "a visible or outward shape, and an inherent shaping impulse." ${ }^{40}$ It relates both to the external/superficial and to the essential/determining. It is through form and its mediational nature that a work registers the world in all its complex dimensions, gives these dimensions a social meaning, and reflects on the process of registration. Realism is this shape which is historically mediated. Indeed, both Williams and Lukács point us towards the processual/compositional character of realism and the essentially unstable, heterogeneous, and paradoxical nature of the real and the realistic (despite it being superficially understood as lifelike/photographic, etc.) within realism. However, neither of them offers any specific thought on the use of mode here. For Williams, modes are mainly genres, such as romance, epic, tragedy, and so on, which are literary expressions of an older, heterogeneous society. The shifting mode of economy, the birth of industrial capitalism and the bourgeois class, and the increasing urbanisation of the rural and new coercive methods of labour practices have made novels into the dominant "mode of consciousness" for the current times. ${ }^{41}$ This reading of mode reminds me of Northrop Frye's longue durée understanding of the word as historical or periodical genres. ${ }^{42}$

On the other hand, I will argue that irony, satire, pastoral, and so on, which are presupposed as a novel's form-giving element, are actually the modes through which realism's formal shape is achieved, and through which form appears to be such a dynamic aesthetic category. A realist work does not simply imitate the "world" (in an uncritical mimetic sense); but "registers" it. The word "register" includes the dual meaning of historical/bureaucratic registration ("to record; to set down [facts, names, etc.] in writing, especially accurately or officially") and of mediated reproduction ("to record in one's mind, heart, or memory; to become aware of, to notice properly"). ${ }^{43}$ Modes are chosen to respond to the historical specificity of a period or a crisis-based event and to represent these specificities adequately. As I will show in this book, the difference between a 
famine-based novel and a contemporary starvation-based one does not lie in their realism, if we read realism as the commitment to describing and demystifying social-historical forces. They lie in the use of modes. Irony and caustic humour in the registration of a catastrophic event is a mode of expression; metafiction is another mode. They do not exist exclusively in a narrative; there can be different modes used within a predominant ironic mode. In fact, in many catastrophe-based realist works, modes shift somewhat quickly in order to register the nature of violence adequately: from documentary to gothic, fantastic to social realist, etc. It is this character of uncertainty and malleability that is definitive of modes. As Chris Baldick writes in his Dictionary of Literary Terms, mode is "[a]n unspecific critical term usually designating a broad but identifiable kind of literary method, mood, or manner that is not tied exclusively to a particular form or genre." ${ }^{44}$ I will contend throughout the book that these unstable, heterogeneous, yet historically specific modes transform the realism of the event-based novels into an experimental and "modernistic" form.

Of course, terms such as "metafictional" or "modernistic" are not generally understood to be realism's properties. Indeed, the divide between what stands as realism and as modernism has seen a long debate. In the famous Brecht-Lukács debate in the 1930s, ${ }^{45}$ the writers highlighted the possibilities realism held both in order to conceptualise the current changes in society and to be used as a medium or force for resisting the contemporary rise of fascism. While Lukács spoke of the dimension of totality within realist art through which it uncovers the major forces shaping social relations and conflicts in the transitional phase of capitalism, Brecht also shared a similar sentiment while being more sympathetic to the experimental aspects within modern art, which he understood as a form of "combative realism": a realism that is contemporary, aesthetically aligned to resistance to capitalist hegemonic dominance, and representative of the people, making them historically and politically aware and consolidated for the fight against fascism. This aspect of the combative or modernistic element within realism has long been argued by George Levine, Fredrick Jameson, and others. In a volume, Adventures in Realism, which pays close attention to the self-conscious, experimental, and modernist character of realism, ${ }^{46}$ Fredric Jameson tells us that since realism is used to represent immediate social crises and greater historical shifts, the established realist modes gradually come to seem less vital ("limited and ossified" in his words). ${ }^{47}$ They are then understood as unable to register deeper structural changes, "the ongoing revolution" or 
"some transitory moment in history," and turn into "targets for the defamiliarizations of the various emergent modernisms, which stigmatize their conventions in the form of satire or absorb and sublimate their narratives into generalized allusions." 48 This is also the point that Joe Cleary makes in his introduction to a journal special issue on "peripheral realisms." 49 Realism and modernism are not oppositional literary forms, but expansions of, and reworking on, the same form produced and qualified by historical shifts in the capitalist world-system: "nineteenth-century realism already contained latent modernisms that broke strongly to the fore only in conditions of systemic crisis and that twentieth- century modernisms may equally have retained latent realisms that may yet find novel articulations in new media or new generic modalities in further moments of crisis." "J0 Jameson adds in the same issue that Third-World writers, the majority of whom sympathise with the Left, predominantly use a realist style, while the constantly modernising impulse of their countries also constitutes and shapes this style. A genuine realism, Jameson follows Lukács in suggesting, is thus "a discovery process, which, with its emphasis on the new and the hitherto unreported, unrepresented, and unseen, and its notorious subversion of inherited ideas and genres [...] is in fact itself a kind of modernism, if not the latter's first form." ${ }^{51} \mathrm{He}$ terms this realism a "modernistic realism," which uses realism's conventions and then undermines them.

Interestingly enough, Jameson recognises the blurred distinctions between realism and modernism in an earlier work we discussed before, $A$ Singular Modernity. For Jameson, every modernism tries to address the social world in idioms and techniques that have not been used before, and this is exactly what every new realism does:

Each realism is also by definition new: and aims at conquering a whole new area of content for its representation. Each wishes to annex what has not yet been represented, what has not yet ever been named or found its voice (and this is why throughout and beyond the age of modernism, there are still new and vibrant realisms to be heard and to be recognized, in parts of the world and areas of social totality into which representation has not yet penetrated). This is to say not only that each new realism arises out of dissatisfaction with the limits of the realisms that preceded it, but also and more fundamentally that realism itself in general shares precisely that dynamic of innovation we ascribed to modernism as its uniquely distinguishing feature. ${ }^{52}$ 
However, he does not discuss the complexities and innovations within realism(s). Modernism appears to be the philosophical-aesthetic response to the conditions of modernity. Since realism is primarily an epistemological category and modernism primarily an aesthetic category, these two are incommensurable and "the attempt to combine the two into a single master narrative must therefore necessarily fail." 53

What I will seek to do in this book is not to combine these categories, but to point out the experimental modes of realism that are "recognisably" modernist, meaning that realist narratives are able to capture the complex dialectical relations of the "situation (modernity) and [the] process" (modernisation) of post/colonial life. I will contend that realism achieves this "modernistic" end predominantly through the use of modes. The "modernizing impulse" in a colonised territory or for a recently decolonised Third-World country, dependent on the First-World for economic reasons, often results in catastrophes: famines, insurgencies, counter-insurgencies, civil war, etc. These postcolonial catastrophes are, thus, world-historical in their formation. But they are also specific in orientation and local in their impact. Novels capture this relation through the use of modes. A Bengal famine, for instance, may have global-historical (colonial) factors responsible for it, but the specificity of Bengali history and culture in the late-colonial period will also have vital influence in the literary registration of the disaster. While there may be stylistic and formal convergences in the late-colonial-based novels on famines across the world, the cultural and historical contingencies, as I will show in the next chapter, will also be notable in their shaping of the literary form. My contention in this book is that: if form is a commitment to understanding how historical processes and historical crisis take place and how the world can be registered in a work, it is mode that offers the framework to do so, retaining the heterogeneity of perspectives and the element of self-reflexivity in fictional writing. It is through the dialectic of form and mode that the dialectic of historical crises and catastrophic events is registered, that epistemology and aesthetics become combined and enabling. I call this framework of realism, produced by a nationalspecific historical conjuncture of postcolonial modernity and a culturally contingent use of modes, as "catastrophic realism."

I will quickly note here that this use is different from Michael Rothberg's close terminology, "traumatic realism." Rothberg discusses the twentieth-century cultural representation of the Holocaust from the analytical categories of trauma and memorialisation. Although for him, 
traumatic realism "mediates between the realist and anti-realist positions in Holocaust studies and marks the necessity of considering how the ordinary and extraordinary aspects of genocide intersect and coexist," realist and anti-realist positions are separate registers. He posits that realism operates, mainly, in the documentary/memoir practices, while modernism is a self-reflexive attempt to render history transparent, and the postmodern moment responds to the questions of emergence and circulation of memory. On the other hand, what I have been arguing in the book is that realism based on catastrophes, or "catastrophic realism" in my use, inheres in it the coexistence of these different registers; here, realism is capacious and expansive, manufactured by the demands of history and society, of catastrophic modernity and modality. Since the book deals not with one event (the Holocaust) but with a set of events and their specific modalities, "catastrophic realism" as an aesthetic framework of postcolonial modernity appears richer, and more dynamic and diverse. I will substantiate this use through a brief critical reading of realism in late-colonial and postcolonial Indian literature, and through Sa'adat Hasan Manto's choice of modes in his pre- and post-Partition fiction.

\section{Writing THE INDian Postcolonial: Framing Catastrophic Realism}

Realism's use has been dominantly experimental and modernistic in the colonies. As Roberto Schwarz has shown, realism was imported and used with irony and parodic elements in the slave-holding economy of Brazil. ${ }^{55}$ In the context of India, as Meenakshi Mukherjee (1985) writes, the colonial novel was influenced by modern European values of individualism, rationality, historical consciousness, and so on; but those did not turn the colonial novel into a case of simple derivation. ${ }^{56}$ As India was predominantly an agricultural country, the main cultural products were oral in form-e.g. jatra (folk theatre) and kathakata (oral recital of the purana stories)——which frequently exploited the topics and narrative elements of the mythological and the supernatural. ${ }^{57}$ Many of the novelists appear to deploy a mythological temporal framework and make heavy uses of allegory, symbol, and fable in their works, where rational-linear progress and cyclical narration converge in the novel of development (Bildungsroman). ${ }^{58}$ Ulka Anjaria (2012) revisits some of these contexts for a work on realism's aesthetic capacities in the late-colonial period. ${ }^{59}$ Anjaria observes 
that writers who used the realist form were agonisingly conscious of India's problematic entrance into historical modernity, where anticipation of a redemptive future and the disillusionment of the present were interconnected. Realism held this paradoxical condition of the impossibility of knowing what was coming next and a faith in a better, more accommodating postcolonial future:

At one level this paradox appears simply in aesthetic gaps: works that are unrealistic, characterization that is unconvincing, plots that are episodic, writing that is overdramatic, and so on. Seen from the perspective of desire, however, these so-called failings can be reinterpreted as representing the coincidence of richness and simultaneous impossibility, of mimesis and metafictionality, that constitute the complex coordinates of realism in the colony. ${ }^{60}$

Through the use of allegory, symbol, or metafictionality, Anjaria adds, writers have engaged politically with the pressing issues of the period and broken open the nationalistic hegemonies of meaning and discourse that clouded critical judgement.

Priyamvada Gopal's use of "critical realism" appears fitting for my context. In Literary Radicalism in India (2005), ${ }^{61}$ Gopal writes that the publication of "Angarey" (1932)-a collection of stories that challenged orthodox notions of community, religion, and gender-and the formation of the All-India Progressive Writers' Association were pivotal for the building of a critical spirit for decolonisation, as opposed to the bourgeois-nationalist discourses of harmony and inclusion. This critical spirit was the product of the country's particular late-colonial historical conjuncture. Borrowing from Gramsci's notion of the "terrain of the conjunctural," "where incurable structural contradictions have revealed themselves (reached maturity)," $" 62$ she argues that, in the context of India's transition from colony to nationhood, the oppositional political force should not be understood only as a passive revolution of Gandhian nationalism, which followed a politics of manoeuvre, neutralising political heterogeneities and promoting a discourse of consensus. Instead, this oppositional force encompasses numerous acts of peasant militancy and labour activism during the period:

The conjunctural terrain of Indian nation formation in the decades just prior to independence in 1947 is marked by the gathering of various forces 
of opposition. Their activities ranged from trade union activism to peasant agitation, and from the secularisation of state institutions to the proliferation of diverse women's organisations. Though inflected by the struggle between British imperialism and Indian nationalism, the activities undertaken by these various forces suggest that a multiplicity of projects were to be undertaken as the transition from colony to nation took place. Gramsci's contention that oppositional forces on the terrain of the conjunctural 'seek to demonstrate that the necessary and sufficient conditions already exist to make possible, and hence imperative, the accomplishment of certain historical tasks' is borne out at this historical conjuncture. ${ }^{63}$

This offers a clear picture of the sociopolitically tempestuous nature of the times. According to Gopal, writers and filmmakers such as M. R. Anand, Premchand, Ismat Chughtai, Sa'adat Hasan Manto, K. A. Abbas, and others were aware of the plural and heterogeneous character of the conjuncture, as well as the tremendous political energies of the period. They argued to retain political and literary heterogeneity in the programmatic (Party-line) use of politics and literature. Their range of experiments in writing and artistic production was meant to preserve literature's critical exploration of the socio-historical dimensions and its "ironic commitment to truth." From this, Gopal contends that realism of the age should be understood as "less a specific aesthetic technique than a philosophy that brings together an affective sense of justice, fairness and harmony with an understanding of all that violates that sense." 64 This definition is powerful as it grasps both the political dimensions of fairness, rights, and entitlement in the practice of realism and in the awareness of their violation in everyday life. Critical realism in such a form appears to express a consciousness of critical solidarity.

My readings of the catastrophic event-based novels also find a similar critical awareness and vision of solidarity. At the same time, during periods of catastrophe and social violence, such as those of the Partition or the famine, socially committed writers have to also address the questions of documentation, analysis, puzzle of incomprehension, and above all, reflection on the act of representation itself. In such a formation, critical realism, I think, does not remain a choice or a question of balance between philosophy and aesthetic techniques. The techniques shape the mode and constitute the philosophy of fractured times. As Sisir Kumar Das and Meenakshi Mukherjee have shown, the social conditions of modernity, the political and economic crisis in the 1930s and 1940s, resulted in the rise of realist novel in India. Kalindi Charan Panigrahi's 
Oriya Matira Manisa (Man of the Soil, 1931), Tarashankar Bandyopadhyay's Bangla Chaitali Ghurni (The Whirlwind, 1932), Nanak Singh's Punjabi Chitta Lahu (White Blood, 1932), A. Bapiraju's Telugu Narayana Rao (Narayana Rao, 1934), Gajanan T. Madkholkar's Marathi Muktatma (Free Soul, 1936), Premchand's Hindi Godaan (The Gift of a Cow, 1936), and Raja Rao's English Kanthapura (1938) have variously narrated the rapid rise of the manufacturing and steel industries in rural areas, the destruction of the handicraft industry and the debilitating agricultural relations, the large migration of rural workers to the city, the native bourgeois elite's exploitation of the peasants, the resistance of the peasants and the subaltern populations, the tension of a looming World War, the general social crisis and the nationalist agitations under Mohandas Karamchand Gandhi, and so on. ${ }^{65}$ These conditions, they have further argued, have also influenced the formal and structural elements of the realist narratives: there are uses of archaic cultural forms, such as the jatra or the kathakata alongside modern and contemporary ones in terms of plot development and characterisation, uses of parallel temporal scales, problematic spatial locations of the narrators, aspects of popular faith in the supernatural and the mythological alongside emerging features of a rationalised subject, and so on. ${ }^{66}$

However, in novels that register catastrophic events such as a famine or a communal riots, there are further developments in form and style. For instance, novels about the 1943 Bengal famine, by Bhabani Bhattacharya, Manik Bandyopadhyay, Tarashankar Bandyopadhyay, or Bibhutibhushan Bandyopadhyay, have demonstrated wide improvisation in narrative form in order to represent the immensity of horror in a society already in deep turmoil as a result of the Second World War and the anti-colonial agitations. In these novels, there are scenes of emaciated hungry people wailing for rice, dying carelessly on the streets, seizing food from their offspring and from animals; scenes of rape and prostitution, of corruption among traders, and of deep entrenchment in class; and scenes of exhibitionism of wealth by the bourgeoisie. The question of how to represent this terrible period of crisis and suffering affected the contemporary writer. The novels, especially those written by socially committed writers (proletarian, working-class, and activist writers, as well as writers critical about the socio-economic exploitation of the poor and the vulnerable), experiment with specific modes, through which they attempt to balance the requirements of the age: to document the current social condition, to analyse the factors responsible for the disaster, and to use literature as a 
social therapy or to reflect on how to represent the pain and suffering of the people. Indeed in novels written much thereafter and that revisit catastrophic events, there are further experimental uses of mode. As I will demonstrate in the next chapter, while the immediate repercussion of the Bengal famine resulted in an analytical-affective mode in Bhabani Bhattacharya, Amlendu Chakraborty writing almost forty years later used a metafictional mode through which he attempted to understand how the famine transitioned into chronic starvation and malnutrition problems - constitutive of postcolonial modernity. The choice of these modes around the same event is then shaped by the immediate and long-term impact of the event. This is why despite studying a historical period of thirty years or so (1943-1977), my research goes beyond the 1970s and finds out how these events have made longer impact in the late 1990s and early 2000s. Through studying these novels with their temporal and spatial proximity with the events, I believe, it will be possible to understand a catastrophe's transition into long-term crisis and its shaping the birth of another catastrophe and so on (i.e. the trajectory of postcolonial modernity or rather modernity-as-catastrophe in postcolonial India). It will also be possible to see how modal choices and experiments are originated by these socio-historical changes and influences, and how writers have attempted to formulate and give voice to the victim communities of these events.

Let me quickly corroborate this point on modal innovation in catastrophe-oriented writing through a reading of Manto's Partition stories. Gopal, who also analyses in her book Manto's writings for an understanding of critical realism, tells us of the difference in critical commentary as well as in the framing of narration in Manto's pre- and post-Partition stories. ${ }^{67}$ In reading one of the post-Partition stories, "Sau Kaindal Power ka Bulb" ("A 100 Candle-Power Bulb"), she notes that Manto, instead of critiquing exploitation of, or speaking fondly about, prostitutes (which he did in his pre-Partition fiction), presents a nameless and stubborn female prostitute who does not want to be understood or sympathised. As the protagonist, sympathetic to her situation, decides to kill the pimp, he discovers in a "nightmarish" scene that she has already killed him and that he is not needed as her fantasied protector. Gopal offers a historical materialist reading of the ending:

It would seem reasonable then to read the story as the critique to end all critiques: a farewell to literary arms and the writerly aspirations to a realism 
that would let the light of day upon the filth and grime that the rest of society refuses to see. That was obviously not to be the case, certainly in terms of Manto's career and continued output. But the argument can certainly be made that the experience of Partition and the devastation that followed chastened the writer and made him aware of the relative modesty of his own and other literary endeavours. It appears, in this instance, to have occasioned an acknowledgement of the limits of what he could, in fact, explain and effect in relation to social transformation. ${ }^{68}$

As I have been arguing, an event of catastrophic nature creates a new consciousness within writers which is not entirely dissevered from the consciousness of the past, but which may require improvisation of existing techniques as well as importation of new modes of expression, and new strategies of narration for adequate representation. Gopal's reading here draws mainly upon sexuality and gender. In many of his post-Partition stories, Manto also focuses on the aspect of madness and of losing sense and speech acts (which can certainly be read through the lens of masculinity and sexuality). In two of the stories, "In the Name of God" and "Open It!" Manto shows how the main characters, respectively, a mother and a father who have lost their children due to the violence, are completely at odds as much with themselves as with the institutions that try to assuage them and create an aura of normality in these times of absolute madness: police station, prison, and medical centre. Indeed, one of Manto's iconic stories, "Toba Tek Singh," is about lunatics in the asylums of Hindustan and Pakistan who, after an order from the governments of these newly formed countries, are about to be exchanged to their family-countries. One lunatic, Bishan Singh, who had some landed property in a town called Toba Tek Singh, comes to know that his land now belongs to Pakistan, while his Sikh family has shifted to Hindustan. On the day of exchange, Bishan Singh, who has been in the asylum for the last fifteen years and been himself named Toba Tek Singh after his endless questions about this place, resists his hand-over and takes a spot in the middle of the borders of the two countries, resolute on his decision. The next day he dies there. The final lines are striking here: "Over there, behind the barbed wires was Hindustan. Over here, behind the identical wires lay Pakistan. In between on a bit of land that had no name, lay Toba Tek Singh." ${ }^{69}$ Consider the restraint in emotion in the language: Manto uses caustic humour throughout the narration to suggest the farcical and meaningless nature of the situation. The case of a 
brief moment of pathos only aggravates the caustic nature: that human bodies have become expendable now, violable and can be killed with impunity, and human community, belonging, and ancestral place have also acquired a contingent meaning. In dying on a land that does not belong to anyone, Toba Tek Singh and his eponymous place appear to declare their resistance against violent disciplining and mapping by the state and against coercive accommodation of their identity. This style of narration also appears in another post-Partition story, "The Dog of Tetwal," in which a stray dog is given national identities by the armies of Pakistan and Hindustan, by stringing cardboard pieces that hold their nations' names around its neck. The dog is killed in the end by both armies for not being loyal enough to either nation. Manto's juxtaposition of the merciless act of dog-killing with the soldiers' sentimental nostalgia for their homes and families and the beautiful spring in the surrounding mountains serves to show that the dog is just a victim of sport, that patriotism can itself bee a murderous act. ${ }^{70}$

The many scenes of violence that characterise the Partition, the madness of killing, and the proliferating case of men and women (and nonhuman animals), whose bodies are now suspended in the middle of chartered territories both geographically and socially, who have lost speech and communicability, or who are puzzled as to why they committed those gruesome acts of violence, compel Manto to take up a narrative mode that is caustic, bitter, reflexive, and deeply satiric, where emotions and analysis merge, although not without restraint. As Gopal correctly notes, there is a "fusion between reason and emotion" in Manto's postPartition stories in contrast to the pre-Partition ones, which "tended to dichotomise emotion and intellect, or metonymy and metaphor."71 This curious shift in the mode of representation of catastrophic crisis is what I have been arguing about in this chapter. Whereas the general social and economic crisis in the late-colonial period resulted in the rise of social and critical realisms, albeit with heterogeneity in formal use, fiction based on catastrophic events gave birth to an innovative use of modal representation within realist writing. There is a tendency to combine analysis with affect in narrating catastrophic events when narration is done from a close distance with them; the mode changes when narration is done from a long distance, such as a fictional work revisiting an event after a long time. While in the case of Partition fiction, Manto's mode of representation changed, there would be, as we will see in the next chapters, uses of a number of modes to attempt to render the catastrophic events 
of famine, peasant insurgency, and emergency in the postcolonial Indian scenario. Like Manto's modal change in pre- and post-Partition fiction, these modes will change according to both the nature of the event and the historical timeframe within which they are represented or addressed to. It is through these complex representational modes that the writers will be understood to have given critical voice to the victim communities.

Here a caution regarding representation needs to be maintained. Giving voice in the literary domain is a far more complex task as it has, among others, two degrees of representation involved. These are, as Gayatri Chakravorty Spivak noted in her widely cited essay on the subaltern, political representation (to speak for) and symbolic representation (to represent in art and philosophy), in which the subaltern's voice is often "unconsciously" elided. ${ }^{72}$ The writers writing about crisis-subjectivity here seem to be aware of this complex interactive duality as they represent the victimised conditions. But what literature or literary realism does further is that it creates its own dualities of aesthetic representation. That the catastrophic events ask for different modes and often a mixture of apparently antithetical modes anticipates how literary realism both derives from and cleaves sociological and historical factors-in course becoming a singular literary event itself. In other words, the writerly representation (of speaking for) allows the artistic-tropological representation to carve out another kind of representation (socio-literary) within the conventions of the literary-aesthetic. As we will see, in Bhabani, Nabarun, Devi, Sahgal, Mistry, and others, this socio-literary representation, constituted by the questions and procedures of giving voice to the victim community (and more often by the failure to do so), will become productive for pointing out literature's act of meaning-making of the catastrophic events or of its differential logic from the sociological.

\section{History and Temporality: Outline of the Chapters}

In the end, a quick note on history and scales of temporality in the book will be useful. While my historical readings range across a period of thirtyfour-odd years from 1943 to 1977, my literary readings begin from 1947 and end in 2003. This is a longer period of around six decades which is not studied chronologically - in terms of the events and their literary outputs-but rather in a way that rallies back and forth in time. Here, a novel written immediately from an event will be read with one written long after. This long-after novel may be found to have surpassed 
literary-temporal registers of the future event. For instance, Amalendu Chakraborty's Ākāler Sandhāne is written historically after the Naxalite insurgency and is shaped by rural starvation conditions that sparked the Naxalbari peasant unrest. This novel uses a literary mode and stylemetafiction and cinematic techniques-which appear dominantly in global writings of the 1970s and 1980s, especially in Mahasweta Devi's Naxalite writings (as will be discussed in this book). However, Chakraborty's and Devi's novels will use two different realist modes because they respond to two divergent yet related historical events and are written from separate temporal locations. This zigzag movement of time, going back and forth, arises from the methodological thrust in the book which argues that while the catastrophic events are unique in their form and character, they are produced by a long-term crisis. These events and their literary modalities of representation need to be read together to understand the modern and catastrophic conditions of life and living in postcolonial India.

Thus, in Chapter 2, I engage with the 1943 Bengal famine, where Bhabani Bhattacharya's So Many Hungers! (1947) is read alongside Amalendu Chakraborty's 1982 novel revisiting the famine, Ākāler Sandhāne (In Search of Famine). Here I explore why and how Bhattacharya has used an "analytical-affective" mode and Chakraborty has employed a "metafictional" mode and what impact they have had on their disaster realism. The Naxalbari peasant insurgency, which rose in the late 1960s and early 1970s, is the subject matter of the Third Chapter. A deeply neglected matter in Indian literary-critical studies, this insurgency resulted in a rich set of literary-artistic texts ranging from novels, poetry, theatre, films, songs, painting, etc. I devote two chapters to this event to both restore the event and its literature and to show how the postcolonial famine-like conditions have led to several social movements culminating in the catastrophic event. These chapters closely read two novels each by Mahasweta Devi and Nabarun Bhattacharya to understand how these writers have represented student-peasant experience in the 1970s and the social conditions of the urban poor in the aftermath of the event, i.e. in the late 1990 s and early 2000s. While I find a dominant use of the "quest" mode in Devi's short novels Hazār Churashir Mā (Mother of 1084, 1974) and Operation? Bashai Tudu (1978), Nabarun's novels (Harbart, 1994; and Kāngāl Mālshāt [Warcry of the Beggars], 2003), in situating the historical link between the Naxalite guerrilla insurgency and the irreal guerrilla warfare by Calcutta's urban poor, use an "urban fantastic mode." I 
contend here that together the quest and the urban fantastic modes comprise the framework of critical irrealism. Finally, in the Fifth Chapter, I write about the continuity of socio-economic crisis and state violence in the late 1960s and the implementation of a nationwide emergency under Indira Gandhi in 1975. I show here that while novelists such as Salman Rushdie (Midnight's Children) have used a "magical realist" mode, novels written from a distance and revisiting the event have used critique and analysis more strongly, especially in the works of Nayantara Sahgal (Rich Like Us) and Rohinton Mistry (A Fine Balance). These "critical realist" modes however complicate class-, gender- and caste-based perspectives. These magical realist and critical realist modes have constituted for me an emergency realism. Together these realisms compose the aesthetic fabric of "catastrophic realism" in postcolonial India.

Before turning to the chapters themselves, I would like to make three final notes. First, this book is in no way an exhaustive reading of novels of catastrophe and crisis in postcolonial India. Neither does it claim that these events together form an exclusive lens through which the nature of Indian postcolonial life and society is to be perceived. One can choose a number of events, such as the Partition, the Indo-Pakistan War, the Bhopal Gas Disaster, and so on. By selecting these events what I have tried to understand is the relation between (colonial) structures of domination, the conditions of life and living for the oppressed and the marginalised in postcolonial times, and the practices and discourses of resistance from below. Here, I have set myself to inquire into what literary form can say about these catastrophic conditions and their traumatising futures, the "continuous" nature of historical crisis. Why is a mode chosen? What does this choice suggest about the reception and registration of an event, of critical solidarity, or of an author's social values? What can a reading of catastrophic realism tell us about Indian postcolonial society in general?

Second, while authors such as Salman Rushdie and Rohinton Mistry have enjoyed a commanding reputation in the field of postcolonial literary studies, Nayantara Sahgal and Bhabani Bhattacharya have been relatively neglected. Mahasweta Devi, despite being adequately translated into English, has limited national and international visibility; and texts by Nabarun Bhattacharya, Amalendu Chakraborty, OV Vijayan and others are hardly known to a wide Indian audience, let alone a global one. It has been a challenging task to read them and to bring them together for a study of historical crisis, catastrophe, and modernity in postcolonial India. 
This task has also been motivated by the desire to retrieve a body of writers who have been either unjustly neglected or violently displaced and relegated to the margins for a certain institutionalised politics of the field of postcolonialism. Through this selection of reading, the book thus aims to offer a counter-genealogy for the postcolonial Indian novel, one that is able to address the questions of historical conditionality of the texts, as well as their nuanced and interrogative uses of literary realism.

Finally, as I proof-check the manuscript and write these words in April 2020, the world witnesses a Coronavirus pandemic. Millions of people are infected, hundreds of thousands have already died, and a global lockdown has been underway for almost two months now. The world and its capitalist speed have come to a standstill. What has been deeply challenging for many of us is to adequately comprehend the strangeness of our realities, where one notices semblances of the normal, in the everyday activities of the humans and the nonhuman animals outside or in vegetation (with the beautiful spring all around and virtual, social media images of a healing, restorative nature), and then juxtaposes them with the cruel bit of information that hundreds and thousands of people are dying everyday of the virus in and around the same place (mostly unseen). These realities have been deeply disturbing on a personal level and yet strangely enriching to this professional work, so much so that I feel more confident about the conjectures, insights, and analyses mobilised in this book. As we attempt to make sense of "our" catastrophic realities and their global yet geo-historically specific impact, it will be useful to note how writers and artists of an era not so long ago have encountered and represented "their" catastrophes and "their" crises through art.

\section{Notes}

1. Jawaharlal Nehru, "A Tryst with Destiny," in Nehru: The First Sixty Years Vol II, ed. Dorothy Norman (New York: John Day, 1965), 336.

2. Although it is only from a particular (class-, caste-, and gender-inflected) position that the country can be said to be slumbering at all.

3. However, the important discontinuities, such as Ambedkar's drafting of the constitution, need to be acknowledged as well.

4. "Catastrophe," OED, https://en.oxforddictionaries.com/definition/ catastrophe [accessed 17 June 2018].

5. Sarkar writes, "By the second half of the nineteenth century, British business houses were in virtual control of the overseas trade, shipping and insurance of the country. So the bulk of the profits from the export boom 
was appropriated by foreign forms and went out of the country as foreign leakage." Sumit Sarkar, Modern India, 1885-1947 (London: Macmillan, 1989), 31.

6. Bishnupriya Gupta, "The Rise of Modern Industry in Colonial India," in A New Economic History of Colonial India, ed. Latika Chaudhary, Bishnupriya Gupta, Tirthankar Roy, and Anand V. Swamy (London: Routledge, 2016): 75-81.

7. Amiya Bagchi, "De-industrialization in India in the Nineteenth Century: Some Theoretical Implications," Journal of Development Studies 12, no. 3 (1976): 135-64; see also Immanuel Wallerstein, "Incorporation of Indian Subcontinent into Capitalist World-Economy," Economic and Political Weekly 21, no. 4 (1986): PE28-PE39. Bagchi's theory supports Dadabhai Naoroji's book of the "drain of wealth" from India. Naoroji has shown through a reading of John Stuart Mill how British merchants systematised an urban-based economy in which the wealth (i.e. revenues) from the rural parts of India was supplied to the metropolitan centres of Britain. See Dadabhai Naoroji, Poverty and Un-British Rule in India (London: Swan Sonnenschein, 1901).

8. Sarkar, Modern India, 36.

9. As Sarkar has noted, there were a number of social movements "from below" by tribals, peasants, artisans, fishermen, etc., in the nineteenth and early twentieth centuries in response to the "disastrous" social conditions in the rural world. The Tebhaga was the result of these various resistance movements produced by the specific colonial-historical conjunctures. Ibid., 43-62.

10. The continual nature of these movements and the fact that the Telangana Uprising started in the same year as India's independence only serve to show that there was no rupture or break, or no awakening from slumber for those on the lowest tier in the socio-economic ladder.

11. Ranajit Guha, "Indian Democracy: Long Dead, Now Buried," Journal of Contemporary Asia 6, no. 1 (1976): 44; for Fanon, see The Wretched of the Earth, 1961, trans. Constance Farrington (London: Penguin, 2001): 119-65.

12. While I use the term "postcolonial" in the book in the dual sense of the historical (after colonial) and the sociological-aesthetic (catastrophic conditions), the term "post/colonial" refers to the period encompassing the (late) colonial and the postcolonial.

13. Fredric Jameson, A Singular Modernity (London: Verso, 2005 ), 99.

14. Sartre writes in Being and Nothingness that one does not choose not to have freedom. Man is "condemned to be free" (449). There are no limits to this freedom. But the outer world can never produce an action by itself. Man has to envision an alternative and to act upon the desire for change. Sartre calls freedom in the outer world as "being-in-itself," and 
the desire to fix a limit and to overcome it as a "situation" or a "beingfor-itself." He writes: "There can be a free for-itself only as engaged in a resisting world. Outside of this engagement the notions of freedom, of determinism, of necessity lose all meaning" (483). He also points out that this desire "to be free" should not be confused with one's subjective wishes. Only in extreme circumstances (Sartre was writing this work as France was occupied by Nazi Germany during the Second World War) can people make significant moral choices and do a fuller use of freedom. I think this applies reasonably to the anti-colonial context, especially to the acts of wrestling social freedom both from the imposing elements of colonial-capitalist modernity and from the native bourgeois dominance of class and culture. See Jean-Paul Sartre, Being and Nothingness: An Essay on the Phenomenological Ontology, trans. Hazel E. Barnes (London: Methuen, 1969).

15. Ibid., 24.

16. Ibid., 27.

17. "[O $]$ ne of the great themes which has conventionally been identified as a dominant in literary modernism - namely temporality itself $[\ldots]$ is very precisely a mode in which this transitional economic structure of incomplete capitalism can be registered and identified as such." Ibid., 142.

18. Indian history has long been periodised in terms of the breaks manufactured by different dominant Indian and foreign empires.

19. Veena Das, Critical Events: An Anthropological Perspective on Contemporary India (New Delhi: Oxford University Press, 1995), 6.

20. Ibid., 5. Emphasis in original.

21. Ibid., 12-13.

22. Das, Events, 18.

23. Ibid., 23.

24. Ibid., 16-17.

25. Dialectic, as Jameson defines the term, is "a conceptual coordination of incommensurabilities [...] a kind of new language strategy, in which both identity and difference are given their due in advance and systematically played off against each other (in ways that for non- or pre-dialectical thought will seem to break the law of non-contradiction)." Jameson, Singular, 64-65.

26. Das, Events, 194-95.

27. Shahid Amin Event, Metaphor, Memory: Chauri Chaura 1922-1992 (Berkeley: University of California Press, 1995), 3.

28. Louis Althusser, "Contradiction and Overdetermination," in For Marx, trans. Ben Brewster (London: Verso, 1990), 126; emphasis in original.

29. Ibid., 112 .

30. Ibid., 114 . 
31. Of course, several dialectical philosophers (from Gillian Rose to Timothy Brennan) have argued that Althusser completely misreads Hegel on this. Indeed, Adorno gave a lecture on "Universal and Particular" around the same time as Althusser's first publication of this essay in a Communist Party journal. Adorno argued that the idea of a particular historical event, understood as a nodal point of crisis in the historical process, was trendy and factual, and instead asked us to look at the Hegelian notion of a universal history, where the particular is stored in as a negative or a "bad" element. This lecture, later published as an essay, seems to challenge Althusser in that what Althusser labours to produce is already available to him in the dialectical tradition. But I also think that it is in Althusser's expression that the relations between historical events and crisis, for my context at least, appear sharp and enabling. For the Adorno essay, see "Universal and Particular," in History and Freedom: Lectures, 1964-1965, trans. Rodney Livingstone (Cambridge: Polity Press, 2008), 10-18.

32. Althusser, “Contradiction," 102.

33. Ibid., 113.

34. Watt considers formal realism as a set of techniques that were meant to represent an older society's transition to capitalist modernity in seventeenth- and eighteenth-century Europe. See Watt, The Rise of the Novel: Studies in Defoe, Richardson and Fielding (Berkeley: University of California Press, 1957), 31.

35. Raymond Williams, Keywords: A Vocabulary of Culture and Society (New York: Oxford University Press, 1985), 258-59.

36. In order to understand the complexities involved in the act of literary mimesis, see Erich Auerbach, Mimesis: The Representation of Reality in Western Literature, trans. William R. Trask, intr. Edward Said (Princeton: Princeton University Press, 2003 [orig. pub: 1953]).

37. Williams, Keywords, 261.

38. Totality, for Lukács, is a "paradoxical fusion of heterogeneous and discrete components into an organic whole which is then abolished over and over again." Lukács, The Theory of the Novel: A Historico-philosophical Essay on the Forms of Great Epic Literature, trans. Anna Bostock (London: Merlin Press, 1971), 84. The realist novel achieves totality through repeatedly bringing and cancelling the organicity of these paradoxical and disparate elements in its use of the devices of irony and narrative perspective, as well as the other features of reflection, mood, chorus/minor characters, etc. (92). Despite the more doctrinaire and strident temper of his writing in later years, Lukács' belief in the roundedness of life, in the possibility through art and aesthetics to uncover the historical conditions of society, and in the essentially historical impulse of realism, never lost track. That is why his celebration of Tolstoy's realism would also emphasise the "indissoluble" character in the writer, where disparate elements would not 
always harmoniously converge. This is also why a more polemical and narrower take on realism in The Meaning of Contemporary Realism would include the "realistic potential" in Franz Kafka, where the nightmarish and improbable statements would be read not as a "straightforward antirealism, but a dialectical process in which realism of detail negates the reality described". See Lukács, The Meaning of Contemporary Realism, trans. John and Necke Mander (London: Merlin Press, 1962). For his uneasy engagement with ETA Hoffmann, see the essay "Marx and Engels on Aesthetics," in Writer and Critic and Other Essays, trans. Arthur D. Kahn (New York: Grosset and Dunlop, 1971), 61-88 (especially 75-80). On Kafka, see "Franz Kafka or Thomas Mann" in The Meaning, 47-92. For his somewhat harsh and seemingly uninformed criticism of Chinese theatrical realism or the realism of Rabindranath Tagore, see Studies in European Realism: A Sociological Survey of the Writings of Balzac, Stendhal, Zola, Tolstoy, Gorki and Others, trans. Edith Bone (London: Merlin Press, 1972), 132, and the review essay of Tagore's Ghare Baire (The Home and the World), 8-11. On Tolstoy, see the long essay "Tolstoy and the Development of Russian Realism," in Studies, 126-206.

39. Lukács writes in The Historical Novel: "[The] historical sense, [which is] already present in practice, of the possibility of generalizing the historical peculiarity of the immediate present, which had been correctly observed by instinct, characterizes the position which the great social novel of England occupies in the development of our problem. It drew the attention of writers to the concrete (i.e., historical) significance of time and place, to social conditions and so on, it created the realistic, literary means of expression for portraying this spatiotemporal (i.e. historical) character of people and their circumstances. But this $[\ldots]$ was a product of realist instinct and did not amount to a clear understanding of history as a process, of history as the concrete precondition of the present." See The Historical Novel, trans. Hannah and Stanley Mitchell (London: Merlin Press, 1962), 18.

40. Raymond Williams, Marxism and Literature (Oxford: Oxford University Press, 1977), 186.

41. Ibid., 190; Terry Eagleton widens this use in his understanding of "literary mode of production," where literature's production of meaning appears to be tied to the material conditions of production. See Terry Eagleton, Criticism and Ideology (London: Verso, 1976), 45-64. I am not stretching the term this far in my use here.

42. Northrop Frye, Anatomy of Criticism: Four Essays (Princeton: Princeton University Press, 1971), 33-35. For Frye, the last fifteen centuries of literary production have offered five predominant modes: myth, romance, high mimetic (epic/tragic), low mimetic (comedy/realistic fiction), and ironic. "During the last hundred years," he writes, "most serious fiction 
has tended increasingly to be ironic in mode" (34-35). Surveying a large corpus of Western literary texts produced within the last two thousand years, he proceeds to show how the ironic mode variously uses the mythical, elegiac, idyllic, or pastoral modes of an older time. Known as archetypal criticism, Frye's framework is insightful for a holistic study. But like Jameson's longue durée framework, it does not do justice to the immediate historical contexts and conjunctures. There is no discussion in Frye as to why a certain mode is chosen, or why it mixes with/brings together different "residual" modes. He does regard the changing social contexts as an influential factor, but the specific contexts are never studied carefully. In the uses of Williams and Frye, then, modes are mainly generic expressions of a long historical time period (34-35).

43. "Register," Oxford English Dictionary Online, University of Warwick Library Database, http://0-www.oed.com.pugwash.lib.warwick.ac. uk/view/Entry/161294? rskey=lsljPJ\&result=3\#eid [accessed 24 April 2017].

44. Chris Baldick, The Oxford Dictionary of Literary Terms, 4th ed. (Oxford: Oxford University Press, 2015), http://0-www.oxfordreference.com. pugwash.lib.warwick.ac.uk/view/10.1093/acref/9780198715443.001. $0001 /$ acref-9780198715443-e-736? rskey=L2SQr7\&result=749 [accessed 16 April 2017].

45. It is to note that there was no formal debate between them but a series of reflections on art and aesthetics, and these reflections were part of a general intellectual dialogue on these matters in a period of fascist rise in Europe. For a look into the individual essays (Georg Lukács, "Realism in the Balance," 28-59, and Bertolt Brecht, "Against Georg Lukács," 68$85)$ as well as the wider contributions to the dialogue, see Aesthetics and Politics, trans. Ronald Taylor (London: Verso, 1977).

46. Adventures in Realism, ed. Matthew Beaumont (Oxford: Blackwell, 2007). Beaumont tells us that the features that the postmodernists celebrate in narratives-self-consciousness, parody, pastiche, and irony-are formative of realism. Realist writers employed a number of experimentations within the form both from the acute awareness of the slipperiness of language and literary devices, and in order to capture the shifting historical impulse of the age. Beaumont offers the working definition that realism is "the assumption that it is possible, through the act of representation, in one semiotic code or another, to provide cognitive as well as imaginative access to a material, historical reality that, though irreducibly mediated by human consciousness, and of course by language, is nonetheless independent of it” (2).

47. Fredric Jameson, "A Note on Literary Realism in Conclusion," in Adventures, 261; for an elaborate reading on this, see his The Antinomies of 
Realism (London: Verso, 2013), especially the chapter, "Realism and the Dissolution of Genre," 138-62.

48. Ibid., 266.

49. Joe Cleary, "Realism After Modernism and the Literary World-System," in "Peripheral Realism", ed. Joe Cleary, Jed Esty, and Collen Lye, Modern Language Quarterly, 73, no. 3 (2012): 255-68.

50. Ibid., 268; in this context, also see the issue of "Worlding Realisms," ed. Lauren M. E. Goodlad in the journal Novel, especially the article, "Realism Wars" by Jed Esty, where Esty argues, like Cleary, that the shifting imperial structures of domination in the early twentieth century, from Britain to the USA (and shifting now towards Asia) have caused writers and critics to see realism as imperialistic and programmatic, and modernism and adventure fiction as its emancipatory opposite. The recent world financial crisis and the contemporary rise of realist fiction may be the beginning of the next phase of realism until the form is understood as saturated and programmatic with the further shift of the imperialist domain. Realism and modernism, according to Esty, are less about aesthetic differences than about geopolitically shaped expressions. Esty, "Realism Wars," Novel: A Forum for Fiction 49, no. 2 (2016): 316-42.

51. Fredric Jameson, "Antinomies of the Realism-Modernism Debate," in "Peripheral Realisms," ed. Joe Cleary, Jed Esty, and Colleen Lye, Modern Language Quarterly, 73, no. 3 (2012): 476.

52. Ibid., 123.

53. Ibid., 124.

54. Michael Rothberg, Traumatic Realism: The Demands of Holocaust Representation (Minneapolis: University of Minnesota Press, 2000), 9.

55. He calls literary form an abstract of specific social relationships through which the process of transformation of social questions into "properly literary ones" is realised. See "The Importing of the Novel to Brazil and Its Contradiction in the Work of Alencar," in Misplaced Ideas: Essays on Brazilian Culture (London: Verso, 1992), 53.

56. Meenakshi Mukherjee, Realism and Reality: Novel and Society in India (New Delhi: Oxford University Press, 1985), 4.

57. Ibid., 56; Mukherjee writes that it is important to "examine the synthesis of borrowed literary form and indigenous aesthetic - as well as cultural expectations - in order to determine the extent to which the form has undergone mutation in the process," 18.

58. Indeed, she also finds extra-literary co-ordinates-such as Indian philosophy, religion, and the moralistic discourses-as well as Indian concepts of history and fiction, as discursively interconnected rather than antagonistic. It is necessary to mention here, as Supriya Chaudhuri has argued, that the Bengali novel was born as a mode of satirical commentary on the imitations of the British and Western cultures and on the lifestyles by 
the Bengali native elites and the nouveau riche. Chaudhuri, "The Bengali Novel," in The Cambridge Companion to Modern Indian Culture, ed. Vasudha Dalmia and Rashmi Sadana (Cambridge: Cambridge University Press, 2012), 102.

59. Ulka Anjaria, Realism in the Twentieth-Century Indian Novel: Colonial Difference and Literary Form (Cambridge: Cambridge University Press, 2012).

60. Ibid., 15 .

61. Priyamvada Gopal, Literary Radicalism in India: Gender, Nation and the Transition to Independence (London: Routledge, 2005).

62. Ibid., 18 .

63. Ibid., 20 .

64. Ibid., 27.

65. For a reading on this, see Sisir Kumar Das, A History of Indian Literature, 1911-1956: Struggle for Freedom: Triumph and Tragedy (New Delhi: Sahitya Akademi, 2015), 276-300.

66. For a reading on this, see Colonialism, Modernity, and Literature: $A$ View from India, ed. Satya P. Mohanty (New York: Palgrave Macmillan, 2011). However, I think Mohanty uncritically dismisses Jameson's views on a singular but uneven/unequal modernity for an argument on alternative/indigenous modernity. See his introduction, especially, 4-6.

67. Manto's pre-Partition stories are marked by "male sexuality and masculinity, on the one hand, and patriarchy and the exploitation of women on the other," while his post-Partition fiction appears "to bring together psychobiography and historical analysis, probing the wounded recesses where individual and community colluded in doing violence to themselves and to others in the cause of self-assertion." Gopal, Radicalism, 93.

68. Ibid., 118.

69. Sa'adat Hasan Manto, “Toba Tek Singh," in Black Margins: Sa'adat Hasan Manto Stories, ed. M. Asaduddin (New Delhi: Katha, 2001), 220.

70. Ibid., 188-99.

71. Gopal, Radicalism, 119.

72. Gayatri Chakravorty Spivak, "Can the Subaltern Speak?," in Marxism and the Interpretation of Culture, ed. C. Nelson and L. Grossberg (Basingstoke: Macmillan, 1988), 275-77.

\section{REFERENCES}

Adorno, Theodore et al. Aesthetics and Politics. Translated by Ronald Taylor. London: Verso, 1977.

Adorno, Theodore. "Universal and Particular." In History and Freedom: Lectures, 1964-1965, translated by Rodney Livingstone, 10-18. Cambridge: Polity Press, 2008. 
Althusser, Louis. "Contradiction and Overdetermination." In For Marx, translated by Ben Brewster, 87-128. London: Verso, 1990.

Amin, Shahid. Event, Metaphor, Memory: Chauri Chaura 1922-1992. Berkeley: University of California Press, 1995.

Anjaria, Ulka. Realism in the Twentieth-Century Indian Novel: Colonial Difference and Literary Form. Cambridge: Cambridge University Press, 2012.

Auerbach, Erich. Mimesis: The Representation of Reality in Western Literature [1953]. Translated by William R. Trask. Princeton: Princeton University Press, 2003.

Bagchi, Amiya. "De-industrialization in India in the Nineteenth Century: Some Theoretical Implications." Journal of Development Studies 12, no. 3 (1976): 135-64.

Baldick, Chris. The Oxford Dictionary of Literary Terms, 4th ed. Oxford: Oxford University Press, 2015. http://0-www.oxfordreference.com.pugwash. lib.warwick.ac.uk/view/10.1093/acref/9780198715443.001.0001/acref9780198715443-e736? rskey=L2SQr7\&result=749. Accessed 16 April 2017.

Beaumont, Matthew, ed. Adventures in Realism. Oxford: Blackwell, 2007.

Chaudhuri, Supriya. "The Bengali Novel." In The Cambridge Companion to Modern Indian Culture, edited by Vasudha Dalmia and Rashmi Sadana. Cambridge: Cambridge University Press, 2012.

Cleary, Joe. "Realism After Modernism and the Literary World-System." In "Peripheral Realism" [special issue], edited by Joe Cleary, Jed Esty, and Collen Lye. Modern Language Quarterly 73, no. 3 (2012): 255-68.

Das, Sisir Kumar. A History of Indian Literature, 1911-1956: Struggle for Freedom: Triumph and Tragedy. New Delhi: Sahitya Akademi, 2015.

Das, Veena. Critical Events: An Anthropological Perspective on Contemporary India. New Delhi: Oxford University Press, 1995.

Eagleton, Terry. 1976. Criticism and Ideology. London: Verso.

Esty, Jed. "Realism Wars." Novel: A Forum for Fiction 49, no. 2 (2016): 316-42.

Frye, Northrop. 1971. Anatomy of Criticism: Four Essays. Princeton: Princeton University Press.

Goodlad, Lauren, M., ed. "Worlding Realisms" [special issue]. Novel: A Forum for Fiction 49, no. 2 (2016): 316-42.

Gopal, Priyamvada. Literary Radicalism in India: Gender, Nation and the Transition to Independence. London: Routledge, 2005.

Guha, Ranajit. "Indian Democracy: Long Dead, Now Buried." Journal of Contemporary Asia 6, no. 1 (1976): 39-53 Fanon, Frantz. The Wretched of the Earth [1961]. Translated by Constance Farrington. London: Penguin, 2001. Gupta, Bishnupriya. "The Rise of Modern Industry in Colonial India." In $A$ New Economic History of Colonial India, edited by Latika Chaudhary, Bishnupriya Gupta, Tirthankar Roy, and Anand V. Swamy, 67-83. London: Routledge, 2016. 
Jameson, Fredric. "Antinomies of the Realism-Modernism Debate." In "Peripheral Realisms" [special issue], edited by Joe Cleary, Jed Esty, and Colleen Lye. Modern Language Quarterly 73, no. 3 (2012): 475-85.

Jameson, Fredric. A Singular Modernity. London: Verso, 2005.

Jameson, Fredric. The Antinomies of Realism. London: Verso, 2013.

Lukács, Georg. "Marx and Engels on Aesthetics." In Writer and Critic and Other Essays, translated by Arthur D. Kahn, 61-88. New York: Grosset and Dunlop, 1971.

Lukács, Georg. Studies in European Realism: A Sociological Survey of the Writings of Balzac, Stendhal, Zola, Tolstoy, Gorki and Others. Translated by Edith Bone. London: Merlin Press, 1972.

Lukács, Georg. The Historical Novel. Translated by Hannah and Stanley Mitchell. London: Merlin Press, 1962.

Lukács, Georg. The Meaning of Contemporary Realism. Translated by John and Necke Mander. London: Merlin Press, 1962.

Lukács, Georg. The Theory of the Novel: A Historico-philosophical Essay on the Forms of Great Epic Literature. Translated by Anna Bostock. London: Merlin Press, 1971.

Manto, Sa'adat Hasan. “Toba Tek Singh.” In Black Margins: Sa'adat Hasan Manto Stories, edited and translated by M. Asaduddin. New Delhi: Katha, 2001.

Mohanty, Satya P., ed. Colonialism, Modernity, and Literature: A View from India. New York: Palgrave Macmillan, 2011.

Mukherjee, Meenakshi. Realism and Reality: Novel and Society in India. New Delhi: Oxford University Press, 1985.

Naoroji, Dadabhai. Poverty and Un-British Rule in India. London: Swan Sonnenschein, 1901.

Nehru, Jawaharlal. “A Tryst with Destiny.” In Nehru: The First Sixty Years Vol II, edited by Dorothy Norman. New York: John Day, 1965.

Oxford English Dictionary Online. "Catastrophe." Oxford English Dictionary Online, University of Warwick Library Database. https://en. oxforddictionaries.com/definition/catastrophe. Aaccessed 17 June 2018.

Oxford English Dictionary Online. "Register." Oxford English Dictionary Online, University of Warwick Library Database. http://0-www.oed.com. pugwash.lib.warwick.ac.uk/view/Entry/161294? rskey=lsljPJ\&result=3\#eid. Accessed 24 April 2017.

Rothberg, Michael. Traumatic Realism: The Demands of Holocaust Representation. Minneapolis: University of Minnesota Press, 2000.

Sarkar, Sumit. Modern India, 1885-1947. London: Macmillan, 1989.

Sartre, Jean-Paul. Being and Nothingness: An Essay on the Phenomenological Ontology. Translated by Hazel E. Barnes. London: Methuen, 1969. 
Schwarz, Roberto. "The Importing of the Novel to Brazil and Its Contradiction in the Work of Alencar." In Misplaced Ideas: Essays on Brazilian Culture. London: Verso, 1992.

Spivak, Gayatri Chakravorty. "Can the Subaltern Speak?." In Marxism and the Interpretation of Culture, edited by C. Nelson and L. Grossberg. Basingstoke: Macmillan, 1988.

Wallerstein, Immanuel. "Incorporation of Indian Subcontinent into Capitalist World-Economy." Economic and Political Weekly 21, no. 4 (1986): PE28PE39.

Watt, Ian. The Rise of the Novel: Studies in Defoe, Richardson and Fielding. Berkeley: University of California Press, 1957.

Williams, Raymond. Keywords: A Vocabulary of Culture and Society. New York: Oxford University Press, 1985.

Williams, Raymond. Marxism and Literature. Oxford: Oxford University Press, 1977. 